\title{
Penggunaan Metode Analisis Komponen Utama untuk Menilai Hubungan antara Sebaran Kasus COVID-19 dan Kelompok
}

\author{
Muhammad Rendana ${ }^{1}$, Puspa Ayu Pitayati², Mona Lestari \\ ${ }^{1} J u r u s a n$ Teknik Kimia, Fakultas Teknik, Universitas Sriwijaya \\ ${ }^{2}$ Program Studi Teknologi Hasil Perikanan, Fakultas Pertanian, Universitas Sriwijaya \\ ${ }^{3}$ Program Studi Ilmu Kesehatan Masyarakat, Fakultas Kesehatan Masyarakat, Universitas Sriwijaya
}

\begin{abstract}
Abstrak
Distribusi usia kasus the novel coronavirus disease-2019 (COVID-19) sedikit berbeda dengan penyakit pernapasan lainnya. Kategorisasi kelompok usia dapat berguna untuk menerapkan kebijakan pengobatan dan jarak sosial yang saat ini banyak dilakukan sebagai salah satu mitigasi terhadap penularan wabah COVID-19. Oleh karena itu, penelitian ini bertujuan untuk mengkaji hubungan jumlah kasus COVID- 19 dan kelompok usia penderita pada tiga kelompok usia yang berbeda yaitu anak-anak, dewasa dan lanjut usia di kota Jakarta. Metode analisis komponen utama digunakan dalam penelitian ini untuk menganalisis profil distribusi usia. Hasil penelitian menunjukkan bahwa sumber utama kasus COVID-19 dipengaruhi oleh kelompok lanjut usia 5I-60 tahun dan >60 tahun, serta kelompok dewasa usia 2 I-30 tahun yang menunjukkan loading factor $>0,6$ ). Jumlah kasus COVID- 19 tertinggi di daerah studi terdapat pada kelompok lanjut usia yang ditemukan lebih banyak terdapat di wilayah timur Jakarta, sedangkan jumlah kasus COVID-19 terendah terdapat pada kelompok dewasa yang lebih banyak terdapat di bagian utara Jakarta. Mempelajari secara detail distribusi usia di antara orang yang terinfeksi penting untuk memberikan wawasan yang lebih mendalam mengenai mekanisme penularan COVID-19.
\end{abstract}

Kata Kunci: Distribusi usia, COVID-19, epidemiologi, analisis komponen utama.

\begin{abstract}
Age distribution of the novel coronavirus disease (COVID-19) cases is slightly different from other respiratory diseases. The age specificity is prominent in employing policies of treatment and social distancing, which is today identified as one of mitigations against COVID-19 outbreak. Therefore, in this study, we aim to examine the relationship between COVID-19 cases and age specificity in three different groups of age such as children (<18 years), adult (19-49 years) and elderly (>50 years) in Jakarta city. Principle component analysis method has been applied in this study in order to analyze age distribution profile. Result of study revealed that the major sources of COVID- 19 cases were influenced by elderly group aged $5 I-60$ years and $>60$ years, and adult group aged $21-30$ years who showed factor loadings were $>0.6$ ). Furthermore, the highest number cases of COVID- 19 in study area was consisted of more elderly group who were found in the east of Jakarta, while the lowest number cases of COVID-19 was consisted of more adult group who were found in the north of Jakarta. Studying the details of age distribution among infected people was important to provide further insights regarding underlying mechanisms COVID-19 transmission.
\end{abstract}

Keywords: Age distribution, COVID-19, epidemiology, principle component analysis.

Korespondensi*: Muhammad Rendana, Jurusan Teknik Kimia, Fakultas Teknik, Universitas Sriwijaya, Universitas Sriwijaya Indralaya 30662, Sumatera Selatan, Indonesia, E-mail: muhrendana@ft.unsri.ac.id, No.Telp: +628I379895949 


\section{Pendahuluan}

Novel Coronavirus (2019-nCoV) atau lebih dikenal sebagai Corona Virus Disease (COVID-19) merupakan masalah kesehatan masyarakat global sejak diumumkan secara resmi bahwa virus corona sebagai pandemi oleh World Health Organization (WHO) atau Badan Kesehatan Dunia pada 11 Maret 2020. ${ }^{1}$ Penyakit ini telah mencapai titik kritis di mana virus menyebar pada skala geografis yang jauh lebih luas yang menyebabkan masalah kesehatan ringan atau sedang hingga berisiko tinggi bagi kelompok lanjut usia dan orang dengan masalah kesehatan menahun. Sampai tanggal 12 Juli 2020, terhitung angka yang dikonfirmasi positif terjangkit COVID-19 mencapai total 12.552 .765 kasus dan dengan angka kematian sebesar 561.617 kasus. $^{2}$

Kasus tertinggi terdapat di kawasan Amerika dengan total 6.540.222 kasus terkonfirmasi, sedangkan untuk kawasan Asia Tenggara memiliki total 1.130.247 kasus terkonfirmasi, sekaligus menjadikan kawasan ini peringkat empat besar dengan jumlah kasus terbanyak di dunia. Indonesia merupakan negara yang terletak di kawasan Asia Tenggara dan salah satu negara penyumbang terbesar peningkatan kasus di kawasan ini. Jumlah kasus terkonfirmasi di Indonesia mencapai angka 75.699 kasus pada 12 Juli 2020, diantaranya 3.606 kematian dan 35.638 sembuh, di mana penyumbang kasus terbanyak di Indonesia berasal dari Kota DKI Jakarta. ${ }^{3}$

Saat ini, jumlah kasus COVID-19 di banyak negara terus meningkat setiap harinya, wabah global ini mulai mengalami titik kritis. Pada beberapa studi kasus dilaporkan bahwa COVID-19 lebih rentan terpapar pada orang lanjut usia (lansia) dengan usia antara 50-69 tahun. ${ }^{4-7}$ Hal ini dikarenakan lansia memiliki daya tahan tubuh yang lebih lemah dibandingkan dengan usia muda lainnya, dan sebagian besar pada usia ini memiliki komorbiditas (penyakit penyerta) yang berkontribusi pada peningkatan risiko infeksi dan penyakit kronis. Di Cina, angka kematian akibat kasus gabungan (COVID-19 dan penyakit penyerta) tersebut sekitar $2 \%$ dan risiko kematian meningkat secara signifikan pada orang tua (sekitar $15 \%){ }^{8}$

Selain itu, penelitian terbaru mengungkapkan bahwa anak-anak dari segala usia dan jenis kelamin rentan terhadap COVID-19. ${ }^{9-10}$ Meskipun gejala COVID-19 pada anak tidak separah penderita dewasa, namun anak-anak masih rentan terhadap infeksi. ${ }^{11}$ Hal ini dikarenakan adanya bukti yang jelas dengan terungkapnya kasus anak-anak yang terinfeksi COVID-19, sehingga meningkatkan kemungkinan bahwa anak-anak dapat menjadi kontributor utama penularan COVID-19. ${ }^{12}$

Sejauh ini, beberapa penelitian telah menganalisis sebaran usia untuk kasus COVID-19, namun tidak dijelaskan sumber utama kasus COVID-19 dan pengaruhnya terhadap rentang usia maupun sebaran tertinggi kasus COVID-19 pada kategori anak, dewasa, dan lansia di suatu daerah. ${ }^{4}$ Oleh karena itu, dengan diketahuinya kelompok usia yang terinfeksi diharapkan dapat memberikan informasi baru terhadap bentuk pengawasan klinis yang akan dilakukan pada semua usia maupun bentuk penerapan kebijakan jarak sosial sebagai upaya menurunkan penyebaran COVID-19. Pada penelitian ini dilakukan pemeriksaan karakteristik usia sebanyak 700 orang yang terinfeksi di DKI Jakarta menggunakan metode analisis komponen utama untuk mengetahui perkaitan jumlah kasus COVID-19 dengan sebaran usia penderita COVID-19 dalam kategori anak-anak, dewasa maupun lanjut usia. Hasil penelitian ini diharapkan memberikan penjelasan lebih lanjut tentang karakteristik epidemilogi kasus COVID-19 di Indonesia.

\section{Metode}

Penelitian ini dilakukan di Provinsi Daerah Khusus Ibukota Jakarta (DKI Jakarta) yang merupakan ibu kota Negara Indonesia. Jakarta menjadi pusat wabah COVID-19 karena memiliki jumlah kasus tertinggi dibanding kota-kota lainnya. ${ }^{3}$ Data usia orang yang terjangkit COVID-19 
diperoleh dari Dinas Kesehatan Daerah Khusus Ibukota Jakarta (www.corona.jakarta.go.id) dari tanggal 25 Maret-17 Juli 2020. Sebanyak 700 data usia orang yang terinfeksi COVID-19 dengan perbedaan jenis kelamin yang diambil secara acak dari 50 kecamatan di Kota DKI Jakarta. Data usia dikumpulkan dari laporan survei usia tertentu seperti $<10$ tahun, 11-20 tahun, 21-30 tahun, 31-40 tahun, 41-50 tahun, 51-60 tahun dan >60 tahun. Kemudian untuk penelitian ini, data usia dikategorikan menjadi tiga kelompok berbeda yaitu anak-anak, dewasa, dan lanjut usia. Selanjutnya, uji reaksi berantai polymerase transcriptase (RT-PCR) oleh dinas kesehatan setempat dilakukan untuk mengetahui kasus yang dicurigai mempunyai kontak dengan pasien terinfeksi. Sebagian besar data pasien bergejala dilakukan perawatan di rumah sakit, sedangkan untuk kasus asimtomatik dilakukan isolasi mandiri di rumah masing-masing.

Metode analisis komponen utama atau Principal Component Analysis (PCA) digunakan dalam penelitian ini untuk mengetahui sebaran kelompok usia orang yang terinfeksi COVID-19 di Jakarta. Teknik ini telah diterapkan secara luas pada studi penyakit dan studi epidemiologi sebelumnya. ${ }^{13-16}$ Metode ini dapat mengidentifikasi keterkaitan dalam variabel observasi atau yang dikenal dengan teknik transformasi orthogonal. ${ }^{17}$ Komponen utama atau Principal Component (PC) dapat dihitung dengan menetapkan variabel sedimikian rupa sehingga variabel pertama menggambarkan proporsi variabilitas terbesar dalam data asli. Penelitian ini menggunakan metode analisis komponen utama karena adanya rotasi varimax yang berguna untuk memastikan setiap variabel saling berhubungan secara maksimal dengan hanya satu komponen kemudian menunjukkan korelasi mendekati nol dengan komponen lainnya. PCA dihitung dengan menggunakan rumus di bawah ini:

$$
P C_{i}=l_{1 i} X_{i}+l_{2 i} X_{2}+\cdots+l_{n i} X_{n}
$$

Di mana $P C_{i}$ menunjukkan komponen utama ke-i dan $l_{n i} X_{n}$ menunjukkan variabel yang diamati $X_{n 15}$. Analisis komponen utama menghasilkan beberapa komponen utama (PC) dari data yang diamati. Nilai Kaiser-Meyer-Olkin dari setiap PC harus lebih besar dari 0,5, untuk dianggap sebagai estimasi terbaik. ${ }^{19}$ Nilai factor loading mampu menunjukkan seberapa besar pengaruh variabel kelompok Usia terhadap PC, di mana semakin tinggi nilai factor loading (mendekati 1.0) menunjukkan penyumbang terkuat sumber penularan COVID-19.

\section{Hasil}

Hasil dari perhitungan menggunakan analisis komponen utama ditabulasikan pada Tabel 1, dimana nilai yang dicetak tebal menunjukkan Faktor loading yang kuat $(>0,5)$.

Tabel 1. Hasil Analisis Komponen Utama

\begin{tabular}{lccc}
\hline \multicolumn{1}{c}{ Variabel } & $\begin{array}{c}\text { Faktor Pertama } \\
(\mathbf{F 1 )}\end{array}$ & $\begin{array}{c}\text { Faktor Kedua } \\
\mathbf{( F 2 )}\end{array}$ & $\begin{array}{c}\text { Faktor Ketiga } \\
\mathbf{( F 3 )}\end{array}$ \\
\hline Usia $<10$ & 0.349 & -0.075 & 0.446 \\
Usia 11-20 & 0.400 & 0.186 & 0.260 \\
Usia 21-30 & -0.174 & -0.244 & $\mathbf{0 . 6 9 8}$ \\
Usia 31-40 & -0.167 & 0.497 & -0.046 \\
Usia 41-50 & 0.407 & 0.351 & -0.251 \\
Usia 51-60 & 0.237 & $\mathbf{- 0 . 6 4 6}$ & -0.416 \\
Usia $>60$ & $\mathbf{- 0 . 6 6 1}$ & -0.029 & -0.08 \\
Nilai Eigen & 1.67 & 1.36 & 1.27 \\
Variabilitas (\%) & 23.83 & 19.39 & 18.17 \\
Kumulatif $(\%)$ & 24.80 & 43.22 & 61.39 \\
\hline
\end{tabular}


Berdasarkan hasil yang diperoleh, hanya factor loading dengan nilai lebih dari 0,5 yang dipilih untuk interpretasi analisis komponen utama. Terdapat tiga faktor (F1, F2, F3) yang dihasilkan setelah rotasi varimax dan analisis komponen utama. Faktor pertama (F1) dan faktor kedua (F2) menunjukan factor loading untuk kelompok lanjut usia, sedangkan untuk faktor ketiga (F3) menunjukan nilai factor loading untuk kelompok dewasa. Faktor pertama (F1) memperoleh nilai variabilitas yaitu $23,83 \%$ (Tabel 1) dari total varian yang menunjukkan factor loading negatif yang kuat pada kelompok usia $>60$ tahun $(-0,661)$. Hasil negatif ini menunjukkan bahwa sebaran kasus COVID-19 tertinggi berkait dengan sedikitnya kelompok usia $>60$ tahun. Berdasarkan hasil analisis komponen utama dari faktor pertama (F1) sebaran kasus COVID-19 tertinggi cenderung berkait dengan kelompok usia 41-50 tahun yang menunjukkan nilai factor loading yang positif (0.407) (Tabel 1). Faktor kedua (F2) memperoleh $19,39 \%$ dari total varian dan menunjukkan factor loading negatif yang kuat untuk kelompok usia 51-60 tahun $(-0,646)$. Selanjutnya, faktor ketiga (F3) diperoleh $18,17 \%$ dari total varian dan menunjukkan factor loading positif yang kuat untuk kelompok usia 21-30 tahun $(0,698)$.

\section{Sebaran Kasus COVID-19 Berdasarkan Kategori Anak, Dewasa dan Lanjut Usia}

Grafik Biplot menunjukkan sebaran usia kasus COVID-19 di Jakarta (Gambar 1). Titik merah menunjukkan kecamatan-kecamatan di Jakarta diplot dalam scatter plot dan garis biru menunjukkan sebaran kelompok Usia.

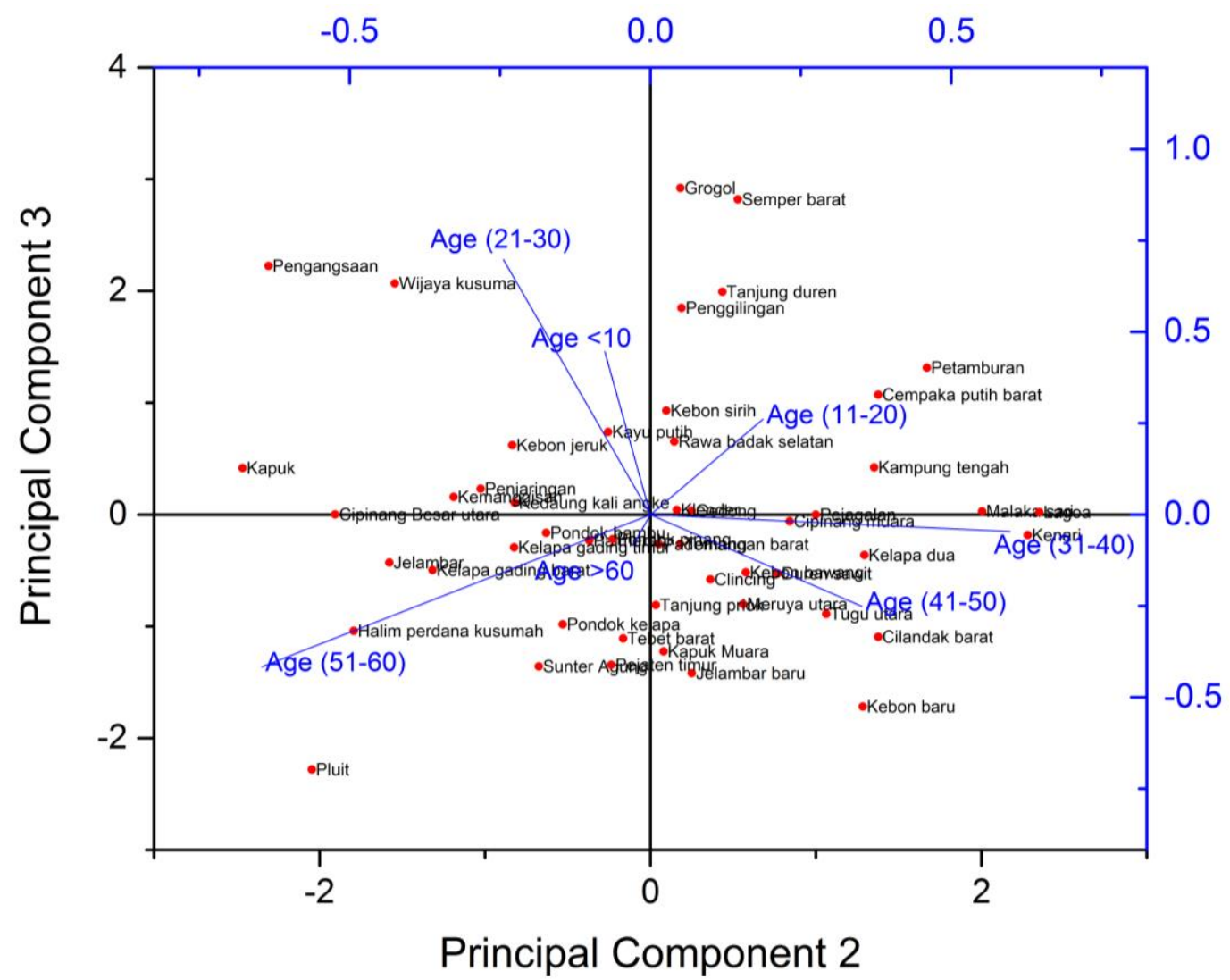

Gambar 1. Grafik Biplot dari Semua Kecamatan Berdasarkan Kelompok Usia

Hasil penelitian menjelaskan bahwa kelompok anak kasus COVID-19 lebih banyak ditemukan di wilayah barat Jakarta (Gambar. 1). Menurut data statistik dari
Dinas Kesehatan Jakarta, Jakarta bagian barat dilaporkan sebagai jumlah kasus COVID-19 tertinggi kedua di wilayah tersebut (Gambar. 2). Selanjutnya, hasil 
penelitian menujukkan bahwa kelompok dewasa kasus COVID-19 lebih banyak ditemukan di wilayah utara Jakarta (Gambar 1) dan Gambar 2 menunjukkan wilayah utara Jakarta merupakan wilayah dengan jumlah kasus COVID-19 paling rendah diantara wilayah lainnya. Sebaliknya, pada penelitian ini diperoleh bahwa kelompok lansia pada kasus COVID-19 lebih banyak tersebar di wilayah timur Jakarta (Gambar. 1), dan dilaporkan bahwa Jakarta Timur memiliki jumlah kasus COVID-19 tertinggi di wilayah ini terkait dengan tingginya jumlah lansia yang terinfeksi di wilayah tersebut pada tanggal 10 Mei 2020 (Gambar 2).

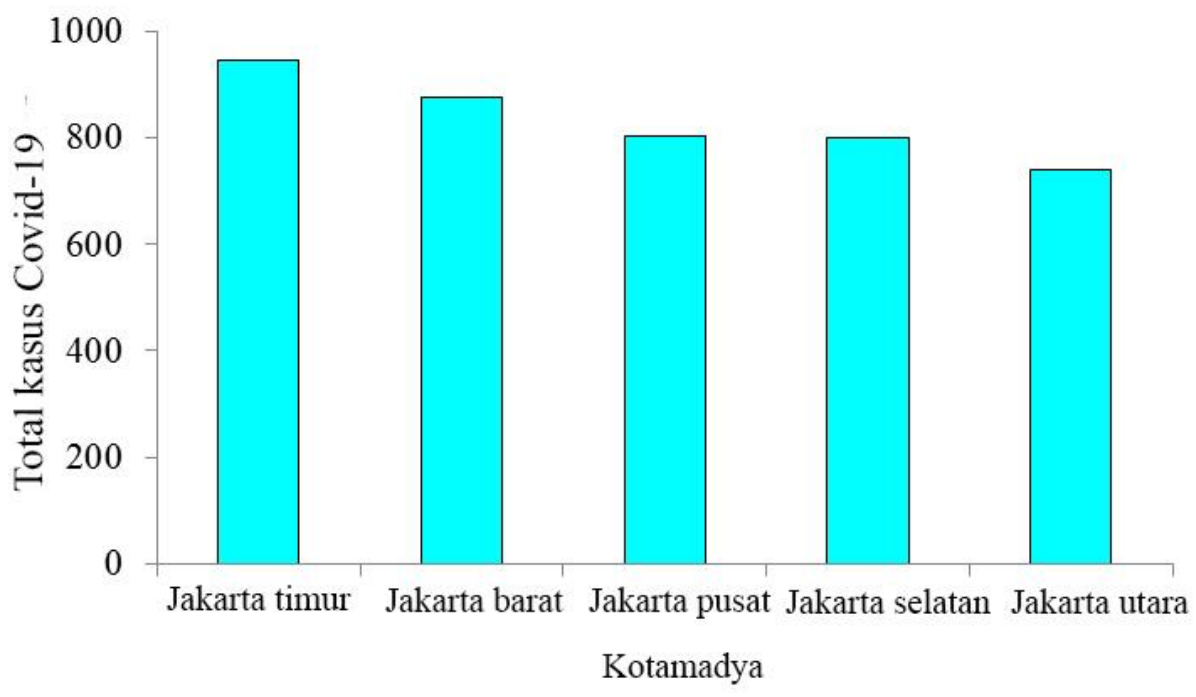

Gambar 2. Sebaran Jumlah Kasus COVID-19 di Jakarta

\section{Pembahasan}

\section{Hubungan Sebaran Kasus COVID-19 dan Kelompok Usia}

Tabel 1 menunjukkan bahwa faktor loading yang kuat terdapat pada kelompok lanjut usia (usia $>60$ tahun dan 51-60 tahun) dan dewasa (usia 21-30 tahun). Sementara, kelompok usia yang lebih muda atau kategori anak-anak menunjukkan hubungan yang lemah dengan factor loading kurang dari 0,50. Hasil penelitian tersebut disimpulkan bahwa sebaran kasus COVID-19 di Jakarta mayoritas terjadi pada kelompok lanjut usia dan dewasa. Hasil ini sejalan dengan penelitian Dudley dan Lee yang mengemukakan bahwa rentang usia 20-29 tahun lebih dominan pada kasus COVID-19 di Republik Korea, sementara di Cina Daratan, jumlah kasus tertinggi berasal dari rentang usia 50-59 tahun dan total kasus kematian meningkat secara dramatis ketika usia bertambah. ${ }^{20}$

Kemungkinan penyebab tingginya angka kasus COVID-19 pada kelompok lanjut usia dan dewasa disebabkan karena tingginya mobilitas penduduk Jakarta sehingga mengakibatkan meningkatnya risiko terjadinya kontak dengan penderita COVID-19. Hal ini berdasarkan hasil penelitian Firdaus dan Wijayanto yang menyatakan bahwa terdapat perbedaan yang signifikan pada masa Pembatasan Sosial Berskala Besar (PSBB) dan new normal terhadap kasus COVID-19, dimana diketahui bahwa mobilitas penduduk pada masa new normal mengalami peningkatan setelah sebelumnya diberlakukan PSBB sehingga menyebabkan rata-rata penambahan kasus baru COVID-19 di Jakarta meningkat menjadi 200,6 kasus per hari. $^{21}$ Hasil penelitian lain juga menyebutkan bahwa faktor mobilitas penduduk merupakan penyebab dominan dalam penyebaran kasus COVID-19 di Jakarta. $^{22}$

Kelompok usia dewasa yang 
merupakan penggolongan usia produktif cenderung memiliki mobilitas yang tinggi, untuk keperluan bekerja atau berekreasi. Penyebaran COVID-19 yang berlangsung melalui transmisi lokal, dimana banyak Orang Tanpa Gejala (OTG) atau carrier, dapat menularkan virus di tengah-tengah masyarakat. Selain itu, kelompok lanjut usia juga merupakan kelompok rentan dimana telah diketahui bahwa daya tahan tubuh mereka melemah seiring bertambahnya usia dan disertai adanya penyakit komorbid yang diderita sehingga mengakibatkan risiko untuk tertular virus tinggi. ${ }^{23-24}$

Penuaan dapat dikaitkan dengan hilangnya kemampuan kekebalan tubuh, yang disebut immunosenescence. ${ }^{25}$ Menurut Calder, immunosenescence mungkin menjadi salah satu faktor yang mempengaruhi kelompok lanjut usia lebih rentan terhadap COVID-19. ${ }^{25}$ Penelitian lain juga menyebutkan bahwa seiring bertambahnya usia, fungsi kekebalan tubuh telah terbukti mengalami disregulasi, sehingga menyebabkan peningkatan risiko terhadap infeksi virus maupun bakteri. ${ }^{26}$ Diketahui dengan mengonsumsi vitamin (A, $\mathrm{B}_{6}, \mathrm{~B}_{12}$, folat, $\mathrm{C}, \mathrm{D}$, dan E) dan trace element (zinc, tembaga, selenium, dan besi) dapat mengurangi risiko terinfeksi dan meningkatkan kekebalan tubuh. ${ }^{25}$

Selain penurunan daya tahan tubuh, kelompok lanjut usia juga cenderung memiliki penyakit penyerta (komorbid), seperti jantung, hipertensi, paru-paru, dan diabetes mellitus. ${ }^{27}$ Di Sumatera Barat, Indonesia, kejadian COVID-19 ditemukan lebih tinggi ketika sebagian besar penduduk memiliki lebih banyak lansia dengan penyakit hipertensi dan diabetes. ${ }^{28}$ Styawan menemukan bahwa hipertensi, jantung, dan diabetes mellitus merupakan penyakit penyerta yang paling banyak dialami oleh penduduk yang terkonfirmasi positif COVID-19 dan meninggal akibat COVID-19. ${ }^{27}$ Dengan demikian, lansia dilaporkan sebagai faktor risiko utama terkait tingginya infeksi COVID-19.

\section{Sebaran Kasus COVID-19 Berdasarkan}

Kategori Anak, Dewasa dan Lanjut Usia

Hasil penelitian menemukan bahwa kasus COVID-19 pada kelompok usia anak-anak paling banyak ditemukan di wilayah barat Jakarta, selain itu, diketahui juga bahwa di wilayah tersebut merupakan wilayah dengan jumlah kasus COVID-19 tertinggi kedua di Jakarta. Tidak diketahui pasti penyebab tingginya kasus COVID-19 pada kelompok usia anak-anak di wilayah barat Jakarta. Untuk itu, perlu dilakukan studi lanjutan terkait hal ini. Sementara, dugaan awal diasumsikan bahwa anak-anak di wilayah barat Jakarta dapat saja tertular dari keluarga di rumah atau orang-orang di lingkungan tempat tinggal. Terdapat spekulasi bahwa orang-orang yang lebih muda seperti anak-anak mungkin saja terpapar dari anggota keluarga dan atau anak-anak lain melalui infeksi orang ke orang. ${ }^{29}$ Bukti tambahan dari alur infeksi tersebut juga telah dilakukan dari penelitian terhadap pasien anak-anak. ${ }^{30}$

Selain itu, mengingat bahwa anak-anak masih butuh pengawasan dari orang dewasa, terutama dalam penerapan protokol kesehatan. Permasalahan yang ditemukan pada anak-anak seperti belum terbiasanya mencuci/membersihkan tangan pakai sabun atau hand sanitizer, jarang atau tidak menggunakan masker, menggunakan masker dengan ukuran yang tidak tepat untuk anak, serta imunitas yang rendah karena gizi buruk, merupakan beberapa hal yang dapat meningkatkan risiko anak untuk terinfeksi COVID-19. Oleh karena itu, pemenuhan asupan gizi dapat melindungi anak dari dalam tubuhnya agar dapat membentuk sistem kekebalan tubuh sehingga terhindar dari berbagai penyakit.

Selanjutnya, pada penelitian ini diperoleh bahwa kelompok usia dewasa kasus COVID-19 lebih banyak ditemukan di wilayah utara Jakarta dan diketahui juga bahwa wilayah ini merupakan wilayah dengan jumlah kasus COVID-19 terendah di Jakarta. Hasil penelitian diketahui bahwa jumlah kelompok rentan seperti lansia di wilayah ini relatif lebih rendah sehingga lonjakan kasus cenderung menjadi rendah. 
Selain itu, kelompok usia dewasa merupakan usia produktif yang memiliki mobilitas tinggi sehingga memiliki peluang yang relatif lebih tinggi untuk terpajan/kontak langsung dengan pathogen dan/atau orang yang terinfeksi (penderita positif COVID-19 atau carrier). Sementara, terdapat juga penelitian yang menyatakan bahwa sistem kekebalan orang dewasa kurang berkembang serta dapat meningkatkan kerentanan terhadap virus dibandingkan dengan sistem kekebalan anak-anak. $^{29}$

Sebaliknya, pada penelitian ini diperoleh bahwa kelompok lansia pada kasus COVID-19 lebih banyak tersebar di wilayah timur Jakarta dan diketahui juga bahwa Jakarta Timur memiliki jumlah kasus COVID-19 tertinggi di wilayah ini, terkait dengan tingginya jumlah lansia yang terinfeksi di wilayah tersebut. Jika dibandingkan dengan studi lain di luar negeri, diperoleh temuan serupa yaitu terkait dengan kasus di Italia $^{31}$ dan China ${ }^{32}$. Di Wuhan, China, Chen et. al. ${ }^{33}$ telah membandingkan karakteristik dari 113 kasus kematian, mereka menemukan bahwa sebagian besar kasus COVID-19 ditemukan pada orang dengan usia hampir 60 tahun. Lansia menjadi kelompok yang paling rentan terhadap infeksi COVID-19 karena umumnya menderita penyakit kardiovaskular, diabetes, hipertensi, penyakit saluran pernafasan kronis dan kanker yang terkait dengan peningkatan risiko penyakit parah. ${ }^{26}$

Terlebih jika penelitian ini dibandingkan dengan kasus virus corona lainnya sebagai contoh di Arab Saudi, Feikin $\mathrm{dkk}^{34}$ melaporkan bahwa faktor risiko tertinggi kasus kematian MERS-CoV adalah pada usia lebih dari 60 tahun. Pada studi lain, menurut penilaian risiko kematian dan keparahan kasus MERS-CoV dari tahun 2012 hingga 2015 di Republik Korea, rata-rata usia pasien MERS-CoV adalah sekitar 50 tahun. $^{35}$ Demikian pula, SARS-CoV-1 juga ditemukan lebih banyak pada lansia di Hongkong. ${ }^{24}$ Berdasarkan hasil penelitian diperoleh $49 \%$ kasus berusia kurang dari 40 tahun, sedangkan 21,5\% kasus berusia di atas 59 tahun dengan rasio kasus fatalitas tertinggi (54,5\%). Singkatnya, terdapat tanggapan serupa pada distribusi usia orang yang terinfeksi antara MERS-CoV dan SARS-CoV-1 dengan COVID-19. Beberapa keterbatasan dalam penelitian ini antara lain faktor usia, penularan COVID-19 yang dapat dipengaruhi oleh sifat alami virus, penyakit keturunan, jenis kelamin, daya tahan tubuh dan lain-lain. Pada penelitian ke depan diharapkan bisa meneliti sifat virus yang kini mulai berubah atau bemutasi sehingga dapat memberikan penanganan yang tepat, penyakit keturunan seperti hipertensi yang menjadi penyakit komorbid tertinggi di Indonesia juga perlu diteliti lebih mendalam. Penelitian saat ini telah meneliti beberapa kategori umur dalam penularan COVID-19, tetapi belum spesifik kepada jenis kelamin pada setiap kategori umur. Selanjutnya, daya tahan tubuh atau imunitas setiap orang juga berbeda yang akan mempengaruhi tingkat penularan virus terhadap seseorang.

\section{Kesimpulan}

Studi ini menyimpulkan bahwa kejadian kasus COVID-19 di Jakarta dipengaruhi oleh kelompok lanjut usia dan dewasa karena nilai factor loading $(>0,60)$ yang terdiri dari rentang usia $>60$ tahun, 51-60 tahun, dan 21-30 tahun. Kasus COVID-19 tertinggi terdapat di wilayah timur Jakarta dengan jumlah lansia yang tinggi. Selain itu, ada kemungkinan kelompok anak-anak dapat menjadi penyumbang penularan COVID-19 karena ditemukan lebih banyak kasus anak di wilayah barat Jakarta dan menjadikan daerah ini menjadi tinggi untuk jumlah kasus yang tertular. Diharapkan studi ini dapat memberikan informasi tambahan baru tentang spesifisitas usia kasus COVID-19 yang mengarah pada peningkatan jumlah kasus di suatu daerah tertentu. Selain itu, perlu adanya penelitian lebih lanjut terkait sebaran COVID-19 pada masing-masing wilayah di Jakarta sehingga diketahui penyebab tingginya kasus COVID-19 pada 
kelompok usia tertentu di wilayah tersebut. Selanjutnya, disarankan juga untuk mempelajari kelompok usia COVID-19 orang yang terinfeksi yang terkait dengan penyakit keturunan atau penyakit kronis umum.

\section{Ucapan Terima Kasih}

Penulis mengucapkan terima kasih kepada Dinas Kesehatan Daerah Khusus Ibukota Jakarta (DKI Jakarta) yang telah menyediakan data kasus dan usia pasien yang terinfeksi COVID-19.

\section{Daftar Pustaka}

1. WHO Director-General's opening remarks at the media briefing on COVID-19 - 11 March 2020". www.who.int (dalam bahasa Inggris). Diakses tanggal 15 April 2021.

2. World Health Organization. Considerations for Quarantine of Individuals in the Context of Containment for Coronavirus Disease (COVID-19): Interim Guidance. 2020.

3. Ministry Health of Indonesia. Guidelines Prevention and Control of Corona Virus Diaseases (COVID-19). 2020.

4. Mizumoto K, Omori R, Nishiura H. Age specificity of cases and attack rate of novel coronavirus disease (COVID-19). medRxiv. 2020. doi: https://doi.org/10.1101/2020.03.09.20033142

5. Daoust JF. Elderly people and responses to COVID-19 in 27 Countries. PLoS One [Internet]. 2020;15(7):1-13. doi: 10.1371/journal.pone. 0235590

6. Sun ZH. Clinical outcomes of covid-19 in elderly male patients. J Geriatr Cardiol. 2020;17(5):243-5.

doi: 10.11909/j.issn.1671-5411.2020.05.010

7. Cortis D. On Determining the Age Distribution of COVID-19 Pandemic. Front Public Heal. 2020;8(May):1-3. doi: 10.3389/fpubh.2020.00202

8. Wu Z, McGoogan JM. Characteristics of and important lessons from the coronavirus disease 2019 (COVID-19) outbreak in China: summary of a report of 72314 cases from the Chinese Center for Disease Control and Prevention. Jama. 2020; 1239-1242. doi: https://doi.org/10.1001/jama.2020.2648

9. Brodin, P. Why is COVID-19 so mild in children?. Acta Paediatrica. 2020: 1082-1083. doi: https://doi.org/10.1111/apa.15271

10. Dong Y, Mo X, Hu Y, Qi X, Jiang F, Jiang Z et al. Epidemiological characteristics of 2143 pediatric patients with 2019 coronavirus disease in China. Pediatrics. 2020; 146. doi: https://doi.org/10.1542/peds.2020-0702

11. Ludvigsson JF. Systematic review of COVID19 in children shows milder cases and a better prognosis than adults. Acta Paediatrica. 2020; 1088-1095. doi: https://doi.org/10.1111/apa.15270

12. Kelvin AA, Halperin S. COVID-19 in children: the link in the transmission chain. The Lancet Infectious Diseases. 2020; doi: https://doi.org/10.1016/S1473-3099(20)30236$\mathrm{X}$

13. Stanturf JA, Goodrick SL, Warren JML, Charnley S, Stegall CM. Social vulnerability and Ebola virus disease in rural Liberia. PLoS One. 2015; 10(9). doi: https://doi.org/10.1371/journal.pone.0137208

14. Shoko C, Chikobvu D, Bessong PO. A Markov model to estimate mortality due to HIV/AIDS using viral load levels-based states and CD4 cell counts: a principal component analysis approach. Infectious diseases and therapy. 2018; 457-471.

doi: https://doi.org/10.1007/s40121-018-0225-y

15. Devrome M, Casteels C, Van der Perren A, Van Laere K, Baekelandt V, Koole M. Identifying a glucose metabolic brain pattern in an adeno-associated viral vector based rat model for Parkinson's disease using 18 F-FDG PET imaging. Scientific reports. 2019; 1-8. doi: https://doi.org/10.1038/s41598-019-48713-0

16. Lim JY, Nam JS, Shin H, Park J, Song HI, Kang $M$ et al. Identification of newly emerging influenza viruses by detecting the virally infected cells based on surface enhanced Raman spectroscopy and principal component analysis. Analytical chemistry. 2019; 5677-5684. doi: https://doi.org/10.1021/acs.analchem.8b05533

17. Shammi M, Bodrud-Doza M, Islam ARMT, Rahman MM. COVID-19 pandemic, socioeconomic crisis and human stress in resource-limited settings: A case from Bangladesh. Heliyon. 2020; 6. doi: https://doi.org/10.1016/j.heliyon.2020.e04063

18. Abdullah $\mathrm{S}$, Ismail $\mathrm{M}$, Ahmed AN. Identification of air pollution potential sources through principal component analysis (PCA). International Journal of Civil Engineering and Technology. 2018; 1435-1442.

19. Voukantsis D, Karatzas K, Kukkonen J, Räsänen T, Karppinen A, Kolehmainen M. Intercomparison of air quality data using principal component analysis, and forecasting of PM10 and PM2. 5 concentrations using artificial neural networks, in Thessaloniki and Helsinki. Science of the Total Environment. 2011; 1266-1276. doi: https://doi.org/10.1016/j.scitotenv.2010.12.039

20. Dudley JP, Lee NT. Disparities in age-specific morbidity and mortality from SARS-CoV-2 in China and the Republic of Korea. Clinical 
Infectious Diseases. 2020. doi: https://doi.org/10.1093/cid/ciaa354

21. Firdaus ZF, Wijayanto AW. Tinjauan Big Data Mobilitas Penduduk Pada Masa Social Distancing Dan New Normal Serta Keterkaitannya Dengan Jumlah Kasus COVID-19. Semin Nas Off Stat. 2021;2020(1):265-72. doi: https://doi.org/10.34123/semnasoffstat.v2020i1 .502

22. Ghiffari RA. Dampak Populasi Dan Mobilitas Perkotaan Terhadap Penyebaran Pandemi COVID-19 Di Jakarta. Tunas Geogr. 2020;9(1):81. doi: https://doi.org/10.24114/tgeo.v9i1.18622

23. Jordan RE, Adab P, Cheng KK. COVID-19: risk factors for severe disease and death. BMJ. 2020; $368 . \quad$ doi: https://doi.org/10.1136/bmj.m1198

24. Leung GM, Hedley AJ, Ho LM, Chau P, Wong IO, Thach TQ et al. The epidemiology of severe acute respiratory syndrome in the 2003 Hong Kong epidemic: an analysis of all 1755 patients. Annals of internal medicine. 2004; 662-673. doi: https://doi.org/10.7326/0003-4819-141-9-2004 11020-00006

25. Calder PC. Nutrition, immunity and COVID-19. BMJ Nutr Prev Heal. 2020;3(1):74-92. doi: https://nutrition.bmj.com/content/3/1/74

26. Siregar FM. Immunosenescence: Penuaan Pada Sel Makrofag. J Ilmu Kedokt. 2019;13(1):14. doi: https://doi.org/10.26891/JIK.v13i1.2019.14-22

27. Styawan DA. Pandemi COVID-19 Dalam Perspektif Demografi. Semin Nas Off Stat. 2021;2020(1):182-9. doi: https://doi.org/10.34123/semnasoffstat.v2020i1 .716

28. Yuniarti E, Indika PM, Dewata I, Heldi H, Barlian E. Komorbidity Mapping of COVID-19
Events in West Sumatera. Sumatra Journal of Disaster, Geography and Geography Education. 2020; 11-16. doi: https://doi.org/10.24036/sjdgge.v4i1.319

29. Dong Y, Mo X, Hu Y, Qi X, Jiang F, Jiang Z et al. Epidemiology of COVID-19 among children in China. Pediatrics. 2020; 145(6). doi: https://doi.org/10.1542/peds.2020-0702

30. Surveillances V. The epidemiological characteristics of an outbreak of 2019 novel coronavirus diseases (COVID-19) - China, 2020. China CDC Weekly. 2020; 113-122.

31. Porcheddu R, Serra C, Kelvin D, Kelvin N, Rubino S. Similarity in case fatality rates (CFR) of COVID-19/SARS-COV-2 in Italy and China. The Journal of Infection in Developing Countries. 2020; 125-128. doi: https://doi.org/10.3855/jidc. 12600

32. Liu K, Chen Y, Lin R, Han K. Clinical features of COVID-19 in elderly patients: A comparison with young and middle-aged patients. Journal of Infection. 2020; e14-e18. doi: https://doi.org/10.1016/j.jinf.2020.03.005

33. Chen T, Wu D, Chen H, Yan W, Yang D, Chen $G$ et al. Clinical characteristics of 113 deceased patients with coronavirus disease 2019: retrospective study. Bmj. 2020; 368. doi: https://doi.org/10.1136/bmj.m1198

34. Feikin DR, Alraddadi B, Qutub M, Shabouni O, Curns A, Oboho IK et al. Association of higher MERS-CoV virus load with severe disease and death, Saudi Arabia, 2014. Emerging infectious diseases. 2015; 21(11). doi: https://dx.doi.org/10.3201\%2Feid2111.150764

35. Mizumoto K, Omori R, Nishiura H. Age specificity of cases and attack rate of novel coronavirus disease (COVID-19). medRxiv. 2020.

doi: https://doi.org/10.1101/2020.03.09.20033142 